\title{
Biotechnology boosts to crop productivity in China: trade and welfare implications
}

Prof. J. Huang

Dr R. Hu

Dr H. van Meijl

Dr F.W van Tongeren

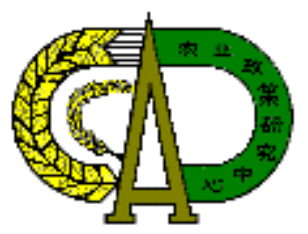

Project code: 61552

October 2002

Report 8.02.06

Agricultural Economics Research Institute (LEI), The Hague 
The Agricultural Economics Research Institute (LEI) is active in a wide array of research which can be classified into various domains. This report reflects esearch within the following domain:

Statutory and service tasks

Business development and competitive position

Natural resources and the environment

Land and economics

Chains

Policy

Institutions, people and perceptions

$\square \quad$ Models and data 
Biotechnology boosts to crop productivity in China: trade and welfare implications

Huang, J., R. Hu, H. van Meijl, F.W. van Tongeren.

The Hague, Agricultural Economics Research Institute (LEI), 2002

Report 8.02.06; ISBN 90-5242-766-6; Price $€ 10,25$ (including 6\% VAT)

39 pp., 1 fig., 12 tab.

Genetically modified (GM) cotton has been widely adopted in China and the list of GM technologies undergoing trials is impressive. However, when China should commercialize its GM food crops is the subject of debate. The overall goal of this report is to provide an economy-wide assessment of these issues under various scenarios. Our results - which are based on unique data from an empirical micro-level study and field trial in China, and from a modified GTAP model - indicate that the development of biotechnology has had and will continue to have an important impact on China's production, trade and welfare. Welfare gains will far outweigh the public biotechnology research expenditures. Most gains will occur inside China. Therefore, policy makers should put less weight on the international dimension when making their decisions about biotechnology development.

Orders:

Phone: 31.70 .3358330

Fax: 31.70.3615624

E-mail: publicatie@lei.wag-ur.nl

Information:

Phone: 31.70 .3358330

Fax: 31.70.3615624

E-mail: informatie@lei.wag-ur.nl

(C) LEI, 2002

Reproduction of contents, either whole or in part, is

$\square \quad$ permitted with due reference to the source. not permitted.

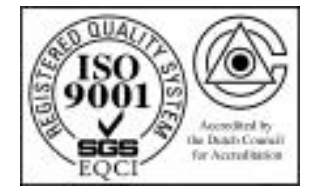

The General Conditions of the Agricultural Research Department apply to all our research commissions. The General Conditions are registered with the Central Gelderland Chamber of Commerce in Arnhem. 


\section{Contents}

Preface

1. Introduction 9

2. Agricultural biotechnology development in China 11

$\begin{array}{lll}2.1 & \text { An overview } & 11\end{array}$

$\begin{array}{ll}2.2 & 12 \\ 2.3 & \text { Research priorities }\end{array}$

$\begin{array}{lll}2.3 & \text { GM cotton and rice } & 13\end{array}$

3. Impact of Bt cotton in China: factor-biased technical change 16

4. Methodology and scenarios 19

$\begin{array}{ll}4.1 \text { Baseline } & 19 \\ 4.2 & \text { Scenaios }\end{array}$

$\begin{array}{lll}4.2 & \text { Scenarios } & 20\end{array}$

5. Economic impact assessment 21

$\begin{array}{lll}5.1 & \text { The impact of commercializing Bt cotton } & 21\end{array}$

5.2 The impact of commercializing both Bt cotton and rice 22

5.2.1 Impact on the rice sector $\quad 22$

$\begin{array}{ll}\text { 5.2.2 Macro impact } & 23\end{array}$

5.2.3 Impact on the other sectors $\quad 24$

5.2.4 Impact in different periods $\quad 25$

5.2.5 Trade impact on the other regions 26

$\begin{array}{lll}5.3 & \text { GMO trade ban on GM rice } & 27\end{array}$

$\begin{array}{lll}5.4 & \text { Labelling } & 28\end{array}$

6. Conclusions $\quad 32$

$\begin{array}{ll}\text { References } & 35\end{array}$

$\begin{array}{ll}\text { Appendix } & 39\end{array}$

Table A Regional and sector aggregations 


\section{Preface}

Because biotechnology - one of this century's most promising and innovative technologies - employs genetic modification techniques, it has spurred worldwide debate. The debate has been going on for decades now and has had a significantly depressing impact on the supply of biotechnology. In the meantime, the demand for the technology has continued to grow.

Genetically modified (GM) cotton has been widely adopted in China and the list of GM technologies undergoing trials there is impressive. Simultaneously, when China should commercialize its GM food crops is a matter of contention. The overall goal of this report is to provide an economy-wide assessment of these issues under various scenarios. Our results - which are based on unique data from an empirical micro-level study and field trial in China, and from a modified GTAP model - indicate that the development of biotechnology has had and will continue to have an important impact on China's production, trade and welfare. Welfare gains will far outweigh the public biotechnology research expenditures. Most gains will occur inside China. Therefore, policy makers should put less weight on the international dimension when making their decisions about biotechnology deve lopment.

This report was prepared for the National Science Foundation of China (projects 79725001 and 70024001) and the Dutch Ministry of Agriculture, Nature and Fisheries as part of the project 'China's food economy in the $21^{\text {st }}$ century'. The research was carried out by Hans van Meijl and Frank van Tongeren of LEI in close cooperation with Jikun Huang and Ruifa $\mathrm{Hu}$ of the Center for Chinese Agricultural Policy (CCAP) and the Chinese Academy of Sciences. This report has benefited from statistical support provided by CCAP staff, in particular the inputs provided by Ninghui Li and Cunhui Fan, and from discussions with Jaap Post and Xiaoyong Zhang of LEI.

The managing director,

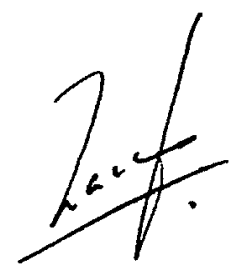

Prof. L.C. Zachariasse 


\section{Introduction}

Because biotechnology - one of this century's most promising and innovative technologies - employs genetic modification techniques, it has spurred worldwide debate. The debate has been going on for decades now and has had a significantly depressing impact on the supply of biotechnology. In the meantime, the demand for the technology has continued to grow: the global area of GM crops increased from 1.7 million ha in 1996 to 52.6 million ha in 2001 (James, 2002).

China was one of the first countries to introduce a GM crop commercially, and currently has the fourth largest GM crop area, after the USA, Argentina and Canada (James, 2002). China's agricultural biotechnology deve lopment is an interesting case and is unique in many respects. The public sector dominates the industry and the list of GM crops undergoing trials differs from those being worked on in other countries where the technologies are dominated by the private sector (Huang et al., 2002a). The Chinese government views agricultural biotechnology as a tool to help China improve the nation's food security, increase agricultural productivity and farmers' incomes, foster sustainable development and improve its competitive position in international agricultural markets (SSTC, 1990). In 2001, approximately four million small farmers in China adopted Bt cotton (Pray et al., 2002).

On the other hand, there is growing concern among policy makers regarding the impact of the ongoing global debate about biotechnology on China's agricultural trade, biosafety and the potential opposition derived from public concerns about the environmental and the food safety of GM products. Because of this, although GM crops are still cultivated in public research institutes, the approval of GM crops (and particularly of food crops) for commercialization has become more difficult since late 1998 (Huang et al., 2001). This reflects the influence of the global debate about GM crops on Chinese policy makers, in particular restrictions on imports to EU countries and on exports from North America. For example, in January 2002 the Ministry of Agriculture (MoA) announced three new regulations on the biosafety management, trade and labelling of GM farm products. These regulations came into effect on 20 March 2002 and require importers of GM agricultural products to apply to China's MoA for official safety verification approval, leading US producers to accuse Beijing of using the new rules to hinder imports and protect Chinese soybean farmers. ${ }^{1}$

China, like many other developing countries, now has to decide how to proceed on the further commercialization of GM crops. Several issues have been raised by policy makers. Should China continue to promote its agricultural biotechnology and commercialize

\footnotetext{
${ }^{1}$ In 2001, China imported about 14 million metric tons of soybeans (mostly RoundUp Ready Soybean) from the USA, Argentina and Brazil. China is also the largest market for US soybean exports, buying more than USD 1 billion's worth in 2001. After two months of intensive negotiations between China and the US, an interim deal was reached in early 2002. China in effect will temporarily waive its regulations and will recognize US assurances that its soybeans are safe for human consumption.
} 
its GM food crops (i.e. rice and soybean)? How important are the trade restrictions imposed on GM products, particularly those imposed by the EU and by other countries in East Asia? What will be the impact of alternative biotechnology policies (in both China and the rest of world) on China's agricultural economy and trade? Answers to these questions are of crit ical importance for policy makers and the agricultural industry. ${ }^{1}$

The aim of drawing up this report is to provide the likely answers to the above questions. To achieve this, the report is organized as follows. In Section 2, a general review of agricultural biotechnology development in China is provided. The impacts of $\mathrm{Bt}$ cotton adoption in China are presented in Section 3. The results from the empirical studies on $\mathrm{Bt}$ cotton and the hypothesized results of GM rice commercialization are the data used for the later simulation analyses with a tailored version of the multi-country general equilibrium GTAP model. Section 4 presents the model and scenarios that are used in the impact assessments. The results of the impacts of alternative biotechnology development strategies are discussed in Section 5. The final section (Section 6) provides concluding remarks and areas for policy actions.

\footnotetext{
${ }^{1}$ Anderson and Yao (2001) recently investigated the potential economic effects of China's adoption of GMOs based on a hypothesized 5\% gain in productivity with GMO adoption. The results show that the effects depend to a considerable extent on the trade policy stance taken in high-income countries opposed to GMOs and on the liberalization of China's trade in textiles and apparel.
} 


\section{Agricultural biotechnology development in China}

\subsection{An overview}

Biotechnology in China has a long history. Several research institutes within the CAAS (the Chinese Academy of Agricultural Sciences), the CAS (the Chinese Academy of Sciences) and various universities initiated their first agricultural biotechnology research programmes in the early 1970 s. $^{1}$ However, the most significant progress in agricultural biotechnology has been made since China initiated a national high-tech programme (the '863' programme) in March 1986. Since then, agricultural biotechnology laboratories have been established in almost every agricultural academy and major university. There are now over 100 laboratories in China involved in transgenic plant research (Chen, 2000). By 2000, eighteen GM crops had been generated by Chinese research institutes; four of these crops have been approved for commercialization since $1997 .^{2}$ GM varieties in such crops as rice, maize, wheat, soybean, peanut, etc. are either in the research pipeline or are ready for commercialization (Chen, 2000; Li, 2000; Huang et 2002a).

A cotton variety with the Bacillus thuringiensis $(\mathrm{Bt})$ gene to control bollworm is one of the most oft-cited examples of the progress of agricultural biotechnology in China. Since the first Bt cotton variety was approved for commercialization in 1997, the total area under Bt cotton has reached nearly 1.5 million ha (2001), accounting for $31 \%$ of China's cotton area (Table 1). In addition, other transgenic plants with resistance to insects, disease and herbicides, or which have been quality-modified, have been approved for field release and are ready for commercialization. These include transgenic varieties of cotton resistant to fungal disease, rice resistant to insect pests and diseases, wheat resistant to the barley yellow dwarf virus, maize resistant to insects and with improved quality, soybeans resistant to herbicides, transgenic potato resistant to bacterial disease, and so on (Huang et al., 2002a).

\footnotetext{
${ }^{1}$ The research focus of biotechnology in the 1970s was cell engineering, tissue culture and cell fusion. Research in cell and tissue culture covered such crops as rice, wheat, maize, cotton, vegetables, etc. (KLCMCB, 1996). Several advanced rice varieties were generated through another culture in the 1970s and 1980s.

${ }^{2}$ These are Bt cotton, tomatoes with resistance to insects or with improved shelf-life, a petunia with altered flower colour, and sweet pepper resistant to diseases. However, before these four crops were approved for commercialization, the first commercial release of a GM crop in the world occurred in 1992 when Chinese farmers first adopted transgenic tobacco varieties. But Chinese farmers have not been allowed to grow GM tobacco since 1995 due to strong opposition from tobacco importers in the USA and certain other countries.
} 


\begin{tabular}{|c|c|c|c|c|c|}
\hline & 1997 & 1998 & 1999 & 2000 & 2001 \\
\hline Cotton area $(x 1000$ ha $)$ & 4,491 & 4,459 & 3,726 & 4,041 & 4,733 \\
\hline Region I & 1,796 & 1,784 & 1,366 & 1,655 & 2,024 \\
\hline Region II & 1,123 & 1,115 & 876 & 922 & 1,147 \\
\hline Region III & 1,572 & 1,561 & 1,484 & 1,464 & 1,562 \\
\hline Bt cotton area $(x 1000$ ha $)$ & 2 & 67 & 400 & 897 & 1,480 \\
\hline Region I & 2 & 60 & 368 & 801 & 1,272 \\
\hline Region II & 0 & 5 & 20 & 81 & 171 \\
\hline Region III & 0 & 2 & 12 & 16 & 37 \\
\hline Bt cotton $(\%)$ & 0 & 2 & 11 & 22 & 31 \\
\hline Region I & 0 & 3 & 27 & 48 & 63 \\
\hline Region II & 0 & 0 & 2 & 9 & 15 \\
\hline Region III & 0 & 0 & 1 & 1 & 2 \\
\hline
\end{tabular}

Note: Region I includes Hebei, Shangdong and Henan, and Region II includes Anhui, Jiangsu and Hubei; the rest of China is in Region III.

Source: Author's surveys.

Progress in plant biotechnology has also been made in recombinant micro-organisms such as soybean nodule bacteria, nitrogen-fixing bacteria for rice and corn, and phytase from recombinant yeasts for feed additives. Nitrogen-fixing bacteria and phytase have been commercialized since 1999. In animals, transgenic pigs and carps have been produced since 1997 (NCBED, 2000). China was the first country to complete the shrimp genome sequencing in 2000 .

\subsection{Research priorities}

Rice, wheat and maize are the three most important crops in China. Each accounts for about $20 \%$ of the total area planted. The production and market stability of these three crops are a prime concern of the Chinese government as they are central to China's food security. National food security, particularly related to grains, is a central goal of China's agricultural and food policy, and has been incorporated into the biotechnology research priority setting (Huang et al., 2001).

China's biotechnology programme has also selected cotton as a targeted crop because of its large sown area, its contributions to the textile industry and trade, and the serious problems with the associated rapid increase in pesticide applications to control insects (i.e. bollworm and aphids). Pesticide expenditures in cotton production in China has increased considerably over the past decades, reaching RMB yuan 834 (approximately USD 100) per ha in 1995. In recent years, cotton production alone has consumed about USD 500 million worth of pesticides annually.

Genetic traits viewed as priorities may be transferred into target crops. Priority traits include those related to insect and disease resistance, stress tole rance and quality improvement (Huang et al., 2002). Pest-resistant traits have priority over all other traits. 
Recently, quality improvement traits have been included as priority traits in response to increased market demand for quality foods. In addition, stress tolerance traits - particularly resistance to drought - are gaining attention as a result of the growing concern over water shortages in northern China.

\subsection{GM cotton and rice}

China is one of the world's leading countries in the production of GM cotton and rice and the related technology (Table 2). The Biotechnology Research Institute (BRI) of CAAS developed insect-resistant $\mathrm{Bt}$ cotton. The $\mathrm{Bt}$ gene's modification and plant vector construction technique was granted a patent in China in 1998. The Bt gene was introduced into major cotton varieties using the pollen tube pathway developed in China (Guo \& Cui, 1998, 2000). By early 2002, sixteen Bt cotton varieties with resistance to bollworms generated by China's public institutions and five Bt cotton varieties from Monsanto had been approved for commercialization in nine provinces.

The BRI recently made another breakthrough in plant disease resistance by developing cotton resistant to fungal diseases (Table 2). Glucanase, glucoxidase and chitnase genes were introduced into major cotton varieties. Transgenic cotton lines with enhanced resistance to Verticillium and Fusarium were approved in 1999 for environmental release (BRI, 2000). 


\begin{tabular}{|c|c|c|c|c|}
\hline Crop & Introduced trait & Field trial & $\begin{array}{l}\text { Environmental } \\
\text { release }\end{array}$ & Commercia lized \\
\hline \multirow[t]{9}{*}{ Cotton } & Insect resistance & & & \\
\hline & Bollworm (Bt) & Yes & Yes & Yes \\
\hline & Bollworm (Bt+CpTI) & Yes & Yes & Yes \\
\hline & Bollworm (CpTI) & Yes & Yes & No \\
\hline & Bollworm (API) & Yes & No & No \\
\hline & Disease resistance & & & \\
\hline & Verticillium \& Fusarium (Chi) & Yes & Yes & No \\
\hline & Verticillium \& Fusarium (Glu) & Yes & Yes & No \\
\hline & Verticillium \& Fusarium (Glu+Chi) & Yes & Yes & No \\
\hline \multirow[t]{11}{*}{ Rice } & Insect resistance & & & \\
\hline & Stem borer $(\mathrm{Bt})$ & Yes & Yes & No \\
\hline & Stem borer (CpTI) & Yes & Yes & No \\
\hline & Rice plant hopper & Yes & Yes & No \\
\hline & Disease resistance & & & \\
\hline & Bacteria blight (Xa 21) & Yes & Yes & No \\
\hline & Fungal disease & Yes & Yes & No \\
\hline & Rice dwarf virus & Yes & Yes & No \\
\hline & Herbicide resistance & Yes & Yes & No \\
\hline & Salt tolerance $(B A D H)$ & Yes & No & No \\
\hline & Ac/Ds (rice mutant $)$ & Yes & No & No \\
\hline
\end{tabular}

Source: Authors' surveys.

More efforts have been put into the GM rice sector. Numerous research institutes and universities have been working on transgenic rice resistant to insects since the early 1990s. Transgenic hybrid and conventional $\mathrm{Bt}$ rice varieties, which are resistant to rice stem borer and leaf roller, were approved in 1997 and 1998 for environmental release (Zhang, 1999). The transgenic rice variety that expressed resistance to the rice plant hopper has been tested in field trials. Through the anther culture, the CpTi gene and the Bar gene were successfully introduced into rice, which expressed resistance to rice stem borer and herbicide (NCBED, 2000; Zhu, 2000).

Transgenic rice with $\mathrm{Xa} 21, \mathrm{Xa} 7$ and $\mathrm{CpTi}$ genes resistant to bacteria blight or rice blast where developed by the Institute of Genetics of CAS, BRI and the China Central Agricultural University. These transgenic rice plants have been approved for environmental release since 1997 (NCBED, 2000). Significant progress has also been made with transgenic plants expressing drought and salinity tolerance in rice. Transgenic rice expressing drought and salinity tolerance has been undergoing field trials since 1998. Genetically modified nitrogen-fixing bacteria for rice was approved in 2000 for commercialization. Technically, various types of GM rice are ready for commercialization. However, the commercializing of GM rice production has not yet been approved because of policy makers' concerns about food safety, rice trade (China exports rice, though the 
amount traded is small compared to its consumption) and its implication for the commercialization of other GM food crops, such as soybean, wheat and maize. 


\section{Impact of Bt cotton in China: factor-biased technical change}

To examine the impact of biotechnology on various input uses and crop yields (after control for input uses) on cotton production, Pray et al. (2001) and Huang et al. (2002b) used both farm budget analysis and a damage control production function approach based on the production practices of 282 cotton farmers (including Bt and non-Bt farmers) in 1999 in Hebei and Shandong provinces, where the bollworm has seriously damaged the local cotton production (Region I in Table 1). A budget analysis by Pray et al. (2001) shows that while there is no significant difference in fertilizer and machinery uses between Bt and non-Bt cotton production, significant reductions were recorded in pesticide and labour use (labour used to spray pesticides). More sophisticated measures based on the same data that applied multivariate regression to estimate the pesticide use and cotton production functions show similar results for the effect of Bt cotton on input uses. The results of their studies reveal that Bt cotton adopters spray $67 \%$ fewer times and reduce pesticide expenditures by $82 \%$ (Huang et al. 2002b). Because the reduction of the farmers pesticide-spraying frequency (from an average of 20 times during one crop season to eight times), Bt cotton technology is also considered a labour-saving technology.

While costs of pesticides and labour inputs are reduced, seed costs of Bt varieties are approximately 100-250\% higher than those of non-Bt cotton by (based on the author's survey in 1999, 2000 and 2001 in five provinces where Bt cotton has been adopted, the price difference between $\mathrm{Bt}$ and non-Bt cotton declined over time). But this is much lower than the market price ratio of Bt cotton seed (40-50 yuan/ $\mathrm{kg}$ ) and non-Bt conventional cotton seed (4-8 yuan $/ \mathrm{kg}$ ) in our sampled areas. The lower seed use per ha in Bt cotton production and farmers' saved Bt cotton seed partly offset the seed price difference.

After controlling for all input differences and geographical location, Huang et al. (2002b) found that adoption of $\mathrm{Bt}$ cotton also impacts on cotton yield. Bt cotton contributed $7-15 \%$ (with an average of about 10\%) of the yield increase in Hebei and Shangdong provinces (Cotton Region I) in 1999. ${ }^{1}$ These results were reconfirmed by two similar surveys conducted in 2000 (which also covered Henan province) and in 2001 (which also covered Anhui and Jiangsu provinces, Cotton Region II). However, new surveys in 2000-2001 also revealed that the extent of the impacts (pesticide and labour inputs, and yield) decline by moving Bt cotton from Region I to Region II (authors' survey).

Based on the above empirical study on Bt cotton adoption and its impact on various inputs and yield, we hypothesize the future patterns of Bt cotton adoption by region and its impact on inputs and yield, and present them in Table 3. All figures in this table represent the difference (as a percentage) of yield and input between Bt cotton and non-Bt cotton. For Bt-cotton adoption and impacts, we have estimated them by region as bollworm and

\footnotetext{
${ }^{1}$ The range of the impacts (7-15\%) reflects the different specifications of the production function models used in the regression. 
other insect diseases differ among the three cotton production regions. The national-level figures are the aggregation of the regional data based on the area shares observed in 2001.

Table 3 Hypothesized yield and input difference (\%) between GM and non-GM crops and GM adoption in 2001-2010

\begin{tabular}{|c|c|c|c|c|c|c|c|}
\hline & \multicolumn{4}{|c|}{ Yield by region } & \multicolumn{3}{|c|}{ Input cost at national level } \\
\hline & National & Region I & Region II & Region III & Pesticide & Seed & Labour \\
\hline \multicolumn{8}{|c|}{ Bt cotton } \\
\hline 2001 & 5.82 & 8.30 & 5.80 & 3.00 & -51 & 120 & -5.1 \\
\hline 2002 & 5.94 & 8.47 & 5.92 & 3.06 & -53 & 120 & -5.3 \\
\hline 2005 & 6.30 & 8.98 & 6.28 & 3.25 & -57 & 120 & -5.7 \\
\hline 2010 & 6.96 & 9.92 & 6.93 & 3.59 & -67 & 120 & -6.7 \\
\hline \multicolumn{8}{|c|}{ GM rice } \\
\hline 2002 & 6.00 & & & & -52 & 50 & -7.2 \\
\hline 2005 & 6.37 & & & & -56 & 50 & -7.9 \\
\hline \multirow[t]{3}{*}{2010} & 7.03 & & & & -65 & 50 & -9.1 \\
\hline & \multicolumn{4}{|c|}{ Adoption rate (\%) } & & & \\
\hline & National & Region I & Region II & Region III & & & \\
\hline \multicolumn{8}{|c|}{ Bt cotton } \\
\hline 2001 & 31 & 63 & 15 & 2 & & & \\
\hline 2002 & 41 & 80 & 30 & 5 & & & \\
\hline 2005 & 79 & 95 & 85 & 55 & & & \\
\hline 2010 & 92 & 95 & 90 & 90 & & & \\
\hline \multicolumn{8}{|c|}{ GM rice } \\
\hline 2002 & 2 & & & & & & \\
\hline 2005 & 40 & & & & & & \\
\hline 2010 & 95 & & & & & & \\
\hline
\end{tabular}

Because the commercialization of GM rice has not been approved yet, an examination of its impacts on rice production inputs and yields is impossible based on the farm-level survey. However, the government has approved a number of insect-, disease- and herbicide-resistant GM rice varieties for field trials and environmental release since the late 1990s. Interviews were conducted in the trial and environmental release areas by the authors. The results of these interviews are used to hypothesize the impacts of GM rice commercialization on rice yield and input uses (Table 3). It should be noted that Table 3 assumes the seed price difference between GM and non-GM varieties to be constant over time. This is a conservative assumption, which may lead to an underestimation of GM gains if seed prices in fact converge to a lower level in the future. On the other hand, the hypothesized adoption rates for rice perhaps overestimate the speed of GM rice adoption.

There is consensus that one cannot simply assume that the GM technologies imply a Hicks-neutral productivity boost as in Anderson and Yao (2001). See for example 
European Commission (2001) for a survey and van Meijl and van Tongeren (2002) for an application to $\mathrm{Bt}$ maize and $\mathrm{Ht}$ soybean technology. The productivity impact of GM technologies in crops is typically factor-biased ${ }^{1}$; that is, cost reductions on some of the production factors can be achieved in varying degrees. The yield increases through GM technology, for example, allow the same volume of output to be produced with fewer units of land. The ultimate effect on total land demand will, however, depend on the interaction of the factor-saving effect (less land relative to other factors) with the expansion effect, as the total output expansion may possibly be larger than the land savings per unit of output. Similarly, the labour savings obtained from less weeding and fewer pesticide sprayings leads to a drop of labour demand at the same level of output. Conversely, more output can be produced with the same amount of labour. The combined effects of factor-biased technical change depend on the relative cost shares of production factors and on the substitution elasticities in the production function. In addition, the general equilibrium model used in this study and discussed in the following section takes also indirect feedback effects through the demand side into account. Increased demand through lower prices in the wake of cost savings will be an important determinant of the sectoral expansion.

\footnotetext{
${ }^{1}$ Factor-biased technical change was introduced by Hicks (1932) to describe techniques that facilitate the substitution of other inputs for a specific production factor. He called techniques that facilitated the substitution of other inputs for labour 'labour saving' and those designed to facilitate the substitution of other input for land, 'land saving'. 


\section{Methodology and scenarios}

\subsection{Baseline}

The impact assessment of Chinese biotechnology developments was made with the help of the well-known GTAP modelling framework. This is a multi-region, multi-sector computable general equilibrium model, with perfect competition and constant returns to scale. The model is fully described in Hertel (1997). This model enables us to incorporate the detailed factor specific GM cost savings as estimated in Section 3. In addition the multi-sector framework captures backward and forward linkages between the GM crops and the using and supplying sectors. In the GTAP model, firms combine intermediate inputs and the primary factors 'land', 'labour' (both skilled and unskilled) and 'capital'. Intermediate inputs are composites of domestic and foreign components, and the foreign component is differentiated by region of origin (Armington assumption). Each region is equipped with one regional household that distributes income across savings and consumption expenditures. Furthermore, there is an explicit treatment of international trade and transport margins, and a global banking sector, which intermediates between global savings and consumption.

The GTAP database contains detailed bilateral trade, transport and protection data characterizing economic relations between regions, linked to individual country inputoutput databases which account for intersectoral linkages between the 57 sectors in each of the 65 regions. All monetary values of the data are in USD million and the base year for the version used in this study (version 5, public release) is 1997. For the purposes of this report, the GTAP database was aggregated into 12 regions and 17 sectors. The aggregation scheme is shown in Table $\mathrm{A}$ in the appendix.

The comparative static model was first used to generate a baseline projection for 2001-2010. In the second step, the impact of alternative biotechnology scenarios was assessed relative to the baseline projection for 2010. The baseline was constructed through recursive updating of the database such that exogenous GDP targets are met, and given exogenous estimates on factor endowments - skilled labour, unskilled labour, capital and natural resources - and population. For this procedure, see Hertel et al. (1999); the exogenous macro assumptions are from Walmsley et al. (2000). The macro assumptions for Asia were updated with recent information from the ADB economic outlook 2002.

The baseline projection also includes a continuation of existing policies and the effectuation of important policy events, as they are known to date. The important policy changes are China's WTO accession between 2002 and 2005; the global phase-out of the Multifibre Agreement under the WTO Agreement on Textiles and Clothing (ATC) by January 2005; and EU enlargement with CEECs.

As well as those macro and policy assumptions, the baseline incorporates new data for the Chinese economy. We have incorporated an updated input-output table for China, which better reflects the size and input structure of agriculture. An important feature of the 
new table is an improved estimate of the primary factors cost shares and crop yields. The new estimates use micro data from farm surveys conducted by a number of ministries led by the State Price Bureau. Another feature of the adjusted database is a drastic adjustment to agricultural trade data for China, which incorporates trade information for 2001. Between 1997 (the base year for GTAP version 5) and 2001 the structure and size of Chinese trade changed dramatically, and we have adjusted the GTAP data to reflect these changes. We also incorporated econometric estimates for income elasticities for livestock products, rice and wheat (Huang \& Rozelle, 1998). The updated estimates for income elasticities are lower than the original GTAP estimates. This matters especially for the medium-term projections for livestock consumption. Given all this base information for 2001, we project the model in two steps: 2001-2005 and 2005-2010. The baseline is more fully documented in van Meijl et al. (2002).

\subsection{Scenarios}

The baseline projection does not contain any assumptions about biotechnology developments. Four scenarios have been developed to assess the policy choices highlighted in the introductory section. The first scenario is designed to study the impact of Bt-cotton adoption in 2010. This impact consists of the part that was realized in 2001 (Tables 1 and 3 ) and the assumed factor-biased productivity gains during the period 2001-2010 summarized in Table 3. We assume that these cost savings affect those farmers who have adopted the GM crop varieties; that is, we weigh the productivity and seed cost estimates by adoption rates to arrive at an average impact on the cotton sector.

The second scenario adds the commercialization of GM rice during 2002-2010 to the adoption of Bt cotton. Again, we used the productivity estimates and adoption rates from Table 3. The third scenario focuses on a possible import ban on GM rice from China. Given that China has commercialized both Bt cotton and GM rice, an import ban on GM rice by its main trading partners is simulated.

Finally, we investigate the effects of the recent regulation on the labelling of imported soybeans that came into effect in March 2002. This scenario is unfolding in the situation where both the cotton and the rice crops have been commercialized. In addition to labelling imported soybeans, the scenario includes the labelling of domestic GM rice. The scenario design is 'additive' (new elements are added one at a time) and we disentangle the separate effects of each new element where appropriate. 


\section{Economic impact assessment}

\subsection{The impact of commercializing Bt cotton}

The farmers' decision to adopt Bt cotton weighs the cost savings due to the ncreased yields, labour-cost savings and reduced pesticide costs against increased seed costs. Table 4 shows the total impact of adopting $\mathrm{Bt}$ cotton and the contributions of these components, relative to the situation without Bt cotton in 2010 . The supply price will be $10.9 \%$ lower in 2010. The yield-increasing and labour-saving impacts of Bt cotton contribute, respectively, $7 \%$ and $3.3 \%$ to this total effect. The pesticide-savings impact lowers the price by $1.7 \%$ while the higher seed price increases the supply price by $1.1 \%$.

Table 4 Main sectoral effects of adopting Bt cotton (percentage change, relative to situation without Bt cotton in 2010)

\begin{tabular}{lrrrrr}
\hline & $\begin{array}{l}\text { Total } \\
\text { impact }\end{array}$ & $\begin{array}{l}\text { Yield } \\
\text { increasing }\end{array}$ & $\begin{array}{l}\text { Labour } \\
\text { saving }\end{array}$ & $\begin{array}{l}\text { Pesticide } \\
\text { saving }\end{array}$ & $\begin{array}{l}\text { Higher seed } \\
\text { price }\end{array}$ \\
\hline Cotton & & & & & \\
Supply price & -10.9 & -7 & -3.3 & -1.7 & 1.1 \\
Output & 4.9 & 3.1 & 1.5 & 0.8 & -0.5 \\
Dom. demand & 4.8 & 3 & 1.5 & 0.8 & -0.5 \\
Exports & 58 & 37.3 & 17.5 & 9 & -5.8 \\
Imports & -16.6 & -10.8 & -4.9 & -2.5 & 3.1 \\
Trade balance & & & & & -71 \\
(USD million) & 389 & 253 & 114 & 59 & \\
Textiles & & & & & 0 \\
Supply price & -0.3 & -0.2 & -0.1 & 0 & 0 \\
Output & 0.7 & 0.4 & 0.2 & 0.1 & 0 \\
Exports & 0.9 & 0.6 & 0.3 & 0.1 & 0 \\
Imports & -0.3 & -0.2 & -0.1 & 0 & -41 \\
Trade balance & & & & & \\
(USD million) & 1,067 & 670 & 341 & 155 & \\
\hline
\end{tabular}

Source: model simulations.

The lower supply price increases demand. Domestic demand increases by $4.8 \%$ and exports by $58 \%$. However, the share of exports in total demand is very low at $0.24 \%$, and export growth therefore contributes only little to the total growth in cotton demand. The rise in domestic demand is almost completely caused by increased demand from the textiles sector. The lower domestic price also implies that cotton imports decrease by 
$16.6 \%$, relative to the 'no-Bt' case. Higher exports and lower imports imply that the trade balance for cotton will improve to the tune of USD 389 million (Table 4).

The textiles sector is the other main sector to benefit from adopting Bt cotton. The lower supply price of cotton implies that the supply price of textiles decreases by $0.3 \%$. The cost share of cotton in textiles amounts to $2.5 \%$ of total cost. The $10.9 \%$ decrease in cotton price leads to a $0.27 \%(-10.9 \% \times 2.5 \%)$ decrease in textiles costs. Output and exports increase by $0.7 \%$ and $0.9 \%$, respectively, while imports decrease by $0.3 \%$. This causes the textiles trade balance to improve to the tune of USD 1067 million.

\subsection{The impact of commercializing both Bt cotton and GM rice}

\subsubsection{Impact on the rice sector}

This scenario assumes GM rice commercialization in addition to the adoption of Bt cotton during the period 2002-2010. This mimics the current adoption process: Bt cotton continues its rapid adoption path, whereas GM rice is yet to be released for commercial purposes. Consequently, the results incorporate both the Bt-cotton effect and the GM-rice effect, but the interaction effects between rice and cotton are negligible. This becomes evident by comparing the second with the third column in Table 5. The adoption of GM rice generates cost savings due to its yield-increasing, labour-saving and pesticides-saving impact. If the adoption takes place according to the assumed scenario, the supply price of rice will be $12 \%$ lower in 2010 . Almost $8 \%$ can be contributed to the yield-increasing impact of GM rice, $4.4 \%$ to the labour-saving impact and $0.9 \%$ to pesticides saving. The higher seed price increases the supply price by $1.1 \%$. Despite the sharp decrease in price, the output response is only $1.4 \%$. This is due to the low income and price elasticities of domestic demand: people do not demand much more rice if the price decreases or their income increases. The increase in exports is very high $(67 \%)$, but the impact on output is limited since only a small portion $(1.2 \%)$ of production is exported.

Table 5 Impact on rice sector of adopting GM rice (percentage change, relative to situation without GM products in 2010)

\begin{tabular}{|c|c|c|c|c|c|c|}
\hline & $\begin{array}{l}\text { Total impact } \\
\text { Bt cotton } \\
\& \text { GM rice }\end{array}$ & $\begin{array}{l}\text { Total impact } \\
\text { GM rice }\end{array}$ & $\begin{array}{l}\text { Yield } \\
\text { increasing }\end{array}$ & $\begin{array}{l}\text { Labour } \\
\text { saving }\end{array}$ & $\begin{array}{l}\text { Pesticide } \\
\text { saving }\end{array}$ & $\begin{array}{l}\text { Higher } \\
\text { seed price }\end{array}$ \\
\hline \multicolumn{7}{|l|}{ Rice } \\
\hline Supply price & -12.0 & -12.1 & -7.8 & -4.4 & -0.9 & 1.1 \\
\hline Output & 1.4 & 1.4 & 0.9 & 0.6 & 0.1 & -0.1 \\
\hline Domestic demand & 1.1 & 1.1 & 0.7 & 0.4 & 0.1 & -0.1 \\
\hline Exports & 66.9 & 66.2 & 43.5 & 24.1 & 5.2 & -5.8 \\
\hline Imports & -23.2 & -23.4 & -15.3 & -8.4 & -1.8 & 2.1 \\
\hline $\begin{array}{l}\text { Change in rice trade } \\
\text { Balance (USD million) }\end{array}$ & 173.2 & 175.1 & 113.8 & 63.1 & 13.7 & -15.5 \\
\hline
\end{tabular}

Source: model simulations. 


\subsubsection{Macro impact}

The commercialization of both GM crops has substantial welfare effects. Table 6 separates aggregate macro effects into the $\mathrm{Bt}$ cotton and $\mathrm{GM}$ rice components. The adoption of $\mathrm{Bt}$ cotton enhances welfare in China by USD 1097 million in 2010. (equivalent variation, EV). This is equivalent to about USD 0.80 per person per year. The adoption of GM rice enhances welfare in China by USD 4155 million (Table 6). The impact is therefore four times greater than in the case of Bt cotton, which is explained by the larger size of the rice sector in 2010. This implies that with the same productivity gains, more resources are saved in the rice sector.

The impact on factor prices varies across factors. Land is a sluggish production factor that is not easily reallocated between alternative uses. Hence we allow for land rent differentials across crops. Land prices decline because factor demand is lower due to the yield increasing effect of the GM technology. At the same time, the output expansion falls short of the yield increase, and consequently less land is demanded in the aggregate.

Macro impact of adopting Bt cotton and GM rice

\begin{tabular}{lccc}
\hline & Bt cotton & GM rice & Total \\
\hline Welfare (EV, USD million) & 1,097 & 4,155 & 5,249 \\
Percentage changes (\%) & & & \\
Factor prices & -0.2 & -2.1 & -2.4 \\
Land & 0.2 & 0.1 & 0.3 \\
Unskilled labour & 0.3 & 0.4 & 0.7 \\
Skilled labour & 0.3 & 0.4 & 0.7 \\
Capital & 0.2 & 0.1 & 0.3 \\
Real exchange rate change (\%) & -671 & $-1,223$ & $-1,894$ \\
Change aggregate trade balance (USD million) & & & \\
\hline
\end{tabular}

Note: The figures do not exactly add up to the amount shown in the 'Total' column because of small interaction effects.

Source: model simulations.

Labour and capital are perfectly mobile across domestic sectors. Although the demand for labour decreases in both crops, the aggregate demand for labour increases. In the cotton case the additional labour demand originates mainly from the unskilled-labour-intensive textiles sector. Due to the positive technical change, the impact on the real exchange rate ${ }^{1}$ improves in both experiments, and this leads to a deterioration of the trade balance.

\footnotetext{
${ }^{1}$ The real exchange rate is defined as the ratio of the regional factor price index relative to a global factor price index. The global factor price index is taken to be the numeraire of the model.
} 


\subsubsection{Impact on other sectors}

The two major price effects of adopting GM rice are the lower price of rice itself and the lower land price. Sectors that use rice or land intensively will therefore achieve the biggest cost gains and can lower their prices and expand output. Land-intensive sectors - such as wheat, coarse grains, cotton and other crops - can use the extra land that is no longer necessary to produce the demanded quantity of rice. The output of other animal products (mainly pork and poultry) will grow because they need land and can use the cheaper coarse grains. Especially the 'Other foods' sector (mainly food processing) can lower its prices because the rice they use as inputs has become much cheaper. This generates an output growth in the 'Other foods' sector, which in turn leads to more intermediate demand for its inputs such as wheat and other crops. relative to situation without GM products)

\begin{tabular}{lccrrr}
\hline price & $\begin{array}{l}\text { Supply } \\
\text { quantity }\end{array}$ & $\begin{array}{l}\text { Output } \\
\text { demand }\end{array}$ & $\begin{array}{l}\text { Consumer } \\
\text { (fob) }\end{array}$ & $\begin{array}{l}\text { Exports } \\
\text { (c.i.f.) }\end{array}$ & Imports \\
\hline Rice & -12.0 & 1.4 & 1.1 & 66.2 & -23.2 \\
Wheat & -0.3 & 0.7 & 0.1 & 1.1 & -0.2 \\
Coarse grains & -0.4 & 0.6 & 0.8 & 0.9 & 0 \\
Oilseeds & -0.1 & 0.6 & 0.2 & 0 & 0.4 \\
Sugar & -0.1 & 0.5 & 0.4 & 0.3 & 0.3 \\
Cotton & -11.4 & 5.1 & 7.2 & 61.9 & -17.4 \\
Other crops & -0.3 & 0.7 & 0.3 & 0.6 & 0.4 \\
Cattle & -0.3 & 0.5 & 0.4 & 0.9 & 0 \\
Other animal products & -0.4 & 0.5 & 0.4 & 1.6 & -0.4 \\
Milk & -0.3 & 0.5 & 0.4 & 0.8 & 0 \\
Fish & -0.6 & 0.6 & 0.6 & 1.4 & -1 \\
Other foods & -1.2 & 1.5 & 0.8 & 4.4 & -2.1 \\
Extract & 0.1 & 0.0 & 0.5 & -0.3 & 0 \\
Textiles/leather & -0.2 & 0.6 & 0.6 & 0.7 & -0.1 \\
Labour-intensive manufacturing & 0.2 & -0.2 & 0.5 & -1.7 & 1 \\
Capital-intensive manufacturing & 0.2 & -0.2 & 0.5 & -1 & 0.6 \\
Services & 0.3 & 0.3 & 0.4 & -1 & 0.9 \\
\hline
\end{tabular}

Source: model simulations.

Although not apparent from Table 7, it should be noted that the effects of GM adoption differ in one important aspect between the two crops: not only is rice a much larger sector than cotton in terms of its contribution to agricultural output and employment, but there are also completely different demand-side effects. Consumers do not demand much more rice if the price is lower or their income is higher. This means that consumers can spend their increased income and the money they save on buying rice on other products. These income effects increase the demand for many other sectors. Such indirect demand effects are not much observed for Bt cotton. 


\begin{tabular}{|c|c|c|c|c|c|c|}
\hline & \multirow{2}{*}{\multicolumn{2}{|c|}{$\begin{array}{c}\begin{array}{c}\text { Past impact } \\
\text { (before 2001) }\end{array} \\
\text { GM rice Bt cotton }\end{array}$}} & \multicolumn{2}{|c|}{$2001-2005$} & \multicolumn{2}{|c|}{$2005-2010$} \\
\hline & & & \multicolumn{2}{|c|}{$\mathrm{GM}$ rice $\mathrm{Bt}$ cotton } & \multicolumn{2}{|c|}{$\mathrm{GM}$ rice $\mathrm{Bt}$ cottor } \\
\hline Supply price & 0 & 0 & -5.1 & 0.1 & -8.6 & 0 \\
\hline Output volume & 0 & 0 & 0.7 & 0 & 1.2 & 0 \\
\hline Export volume & 0 & -0.2 & 23.6 & -0.1 & 37.9 & -0.2 \\
\hline Trade balance (USD mil.) & 0 & -1 & 74 & -1 & 139 & -1 \\
\hline \multicolumn{7}{|l|}{ Cotton } \\
\hline Supply price & 0 & -3.7 & -0.2 & -6.2 & -0.3 & -3.4 \\
\hline Output volume & 0 & 1.4 & 0 & 2.8 & 0.1 & 1.6 \\
\hline Export volume & 0 & 16.5 & 0.7 & 26.4 & 1.1 & 12.8 \\
\hline Trade balance (USD mil.) & 0 & 62 & 3 & 127 & 9 & 95 \\
\hline \multicolumn{7}{|l|}{ Macro } \\
\hline Welfare (USD mil.) & 0 & 289 & 1474 & 511 & 2697 & 303 \\
\hline
\end{tabular}

Source: model simulations.

\subsubsection{Impact in different periods}

Table 8 shows the impact of adopting Bt cotton and GM rice over time. The incremental contribution of adoption within three periods is given. The first two columns show the impact of past adoption (i.e. already achieved in 2001). In 2001 the welfare gain due to the adoption of Bt cotton (the adoption rate is 31\%; see Table 3) is USD 289 million, which is $26 \%$ of the total welfare gain of Bt cotton realized by 2010. GM rice is not yet adopted and hence there are zero welfare effects in 2001. The gains from adopting Bt cotton follow an $\mathrm{S}$-shaped adoption curve. The additional gains of increased adoption are highest in the period 2001-2005 (46\% of welfare gain achieved in 2001) and slow down in the period 2005-2010, as most farmers that potentially adopt have already switched to the new varieties ( $25 \%$ of the total welfare gains in 2010 are added in the last period). For GM rice, all the benefits are still to come from 2001 onward. Between 2001 and 2005, the adoption rate of GM rice climbs from 0 to $40 \%$, and 35\% of welfare gains in 2010 are realized. In the period 2005-2010, the adoption rate increase from $40 \%$ to $95 \%$, and China is expected to arrive at the steep part of the adoption curve and a large part of the potential gains will be realized. Figure 1 shows the cumulative land productivity gains obtained endogenously from the simulations. Land productivity is defined here as the ratio of output to land use. Figure 1 displays the change of this ratio, cumulated over the simulation period. Again, the $\mathrm{S}$-shaped curve for Bt cotton and GM rice indicates that the productivity gains will level 
off in the future. This pattern is well known from the 'green revolution' that dramatically improved rice yields in the 1970s. The productivity growth is not perpetual.

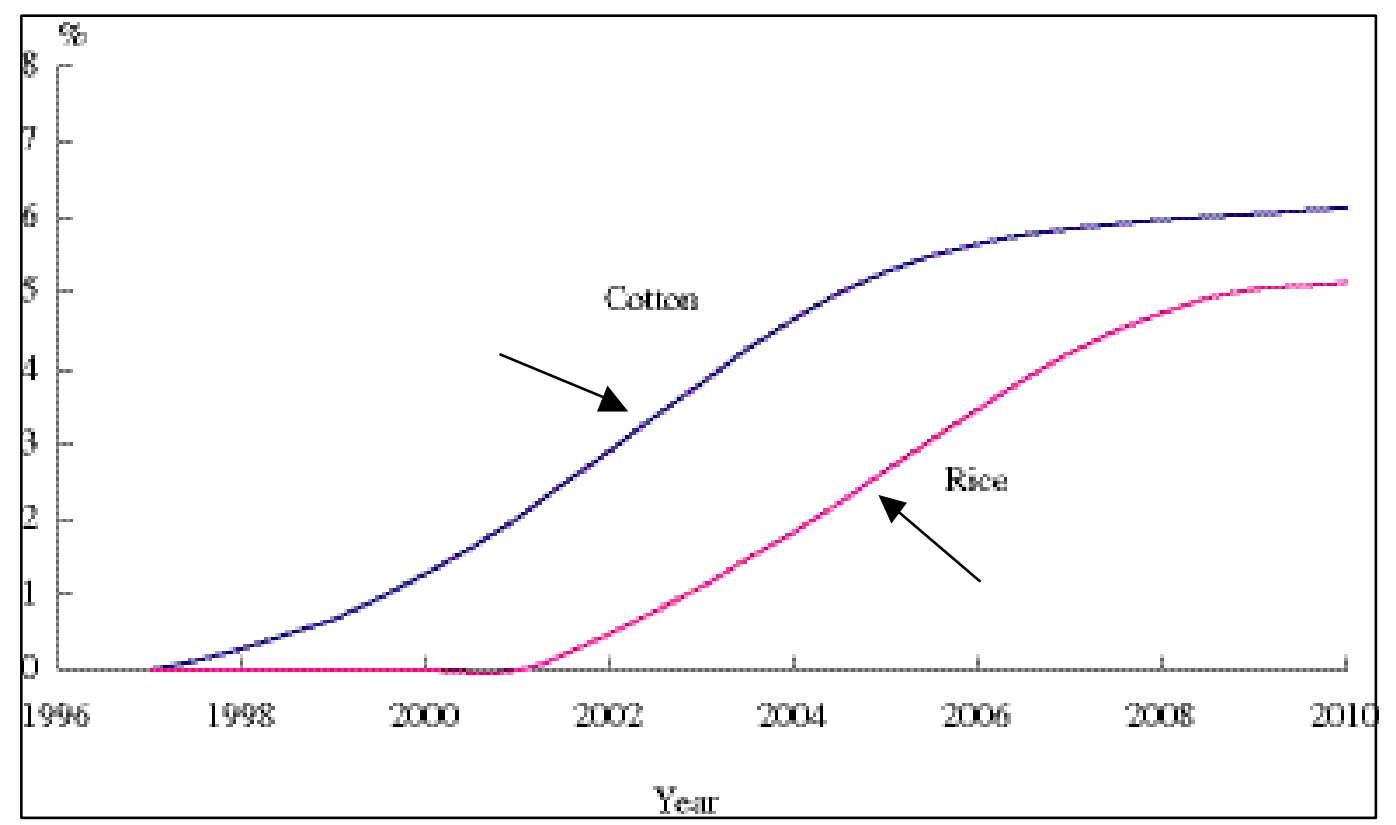

Figure $1 \quad$ Cumulated productivity growth rates over time

Note: the graph is obtained from a Spline interpolation of simulated ratios of output growth over land use in 1997, 2000, 2005 and 2010.

\subsubsection{Trade impact on other regions}

Although China witnesses rising exports and/or reduced imports as a consequence of rapid GM adoption, the patterns of global trade in both the textiles and garments sector and the rice sector are not affected very much. Table 9 presents the changes in the regional trade balance relative to the 'no-GM' case in 2010. The impact is negligible on major rice importers (e.g. Africa and some rice-deficit developing countries in Asia) as well as major rice exporters in Southeast Asia (i.e. Thailand, Vietnam and Burma). The Chinese biotechnology research strategy has in the first place concentrated on crops that are of great importance to rural livelihoods, rather than on those that are important in terms of export earnings. Rice exports from China represent only a small share of the international rice trade. 


\begin{tabular}{|c|c|c|c|c|c|c|}
\hline & \multirow{2}{*}{$\frac{\text { Rice change }}{\text { (USD million) }}$} & \multirow{2}{*}{$\%$} & \multicolumn{2}{|c|}{ Cotton change } & \multicolumn{2}{|c|}{ Textiles change } \\
\hline & & & (USD million) & $\%$ & (USD million) & $\%$ \\
\hline China & 173 & 62 & 408 & 43 & 756 & 1 \\
\hline Hong Kong & 1 & 0 & 1 & -1 & -25 & -2 \\
\hline Taiwan & -1 & -12 & 2 & 1 & -73 & -1 \\
\hline Japan + Korea & -6 & -2 & 6 & 1 & -124 & -10 \\
\hline Southeast Asia & -68 & -14 & 7 & 0 & -100 & -1 \\
\hline Other Asia & -26 & -2 & -12 & -19 & -59 & 0 \\
\hline Aus. + NZ & -5 & -3 & -51 & -5 & -4 & 0 \\
\hline NAFTA & -21 & -4 & -203 & -8 & -137 & 0 \\
\hline SAM & -10 & -7 & -6 & -1 & -50 & -1 \\
\hline EU & -11 & -2 & 1 & 0 & -270 & -1 \\
\hline CEEC & -2 & -2 & 0 & 0 & -20 & -1 \\
\hline ROW & -23 & -1 & -132 & -4 & -67 & 1 \\
\hline
\end{tabular}

The immediate impact is small on other major cotton exporters, most notably India and Pakistan, which are part of our 'Other Asia' region. The cost savings and yield increases from Bt cotton translate into lower production costs for the Chinese textiles and garments industry, but these cost reductions are not of such orders of magnitude that other garment producers (e.g. India and Bangladesh) are affected very much. The phasing out of the Multifibre Agreement by 2005 is of greater importance for global textiles and garments trade than Bt cotton commercialization in China.

\subsection{GMO trade ban on GM rice}

In this scenario China is engaged in producing both Bt cotton and GM rice. However, consumer concerns lead to a ban on GM food products. More specifically, the enlarged EU along with Japan, Korea and Southeast Asia ban GM rice imports from China. Technically, this is modelled as a taste shift against Chinese rice imports that reduces these countries' imports of Chinese rice to zero.

Exports of GM rice from China decline substantially. Whereas an increase in rice exports volume of $67 \%$ was projected when both GM rice and Bt cotton are adopted, the trade ban results in a drop to just 5\% of additional exports relative to the baseline result for 2010 (Table 10). This follows directly from the export shares in the baseline situation in 2010 (without all the biotech shocks), which amount to 21\%, 8\% and 9\% for Southeast Asia, Japan + Korea and the EU27, respectively. Rice output is also declining, by $0.5 \%$ $(1.4 \%-0.9 \%=0.5 \%$, Table 10$)$. The drop is limited, because the share of exports in production is only $1.2 \%$. The rice trade balance deteriorates by USD 154 million (273-19, Table 10) and welfare in China decreases by USD 20 million. 


\section{China}

Rice exports (\% change)

Rice output (\% change)

Change in rice trade balance (USD million)

Welfare (USD million)

Other regions

Japan + Korea welfare (USD million)

Southeast Asia welfare (USD million)

EU-27 welfare (USD million)

$\begin{array}{rr}67 & 5 \\ 1.4 & 0.9 \\ 173 & 19 \\ 5,249 & 5,229 \\ & \\ 298 & 212 \\ 13 & -33 \\ -7 & -52\end{array}$

Source: model simulations.

Table 10 also shows the welfare effects for the countries imposing the ban. The welfare impact is negative but not substantial in these countries: together these countries forego USD 177 million. The negative welfare effect is due to a negative taste effect (some consumers cannot buy their favourite Chinese rice). But it should also be noted that we do not take into account the possible positive impact on the utility of consumers in these countries, which may arise from the banning of GM foods. Consequently, the welfare estimate is perhaps more accurately described as an economic cost estimate of banning. As well as the taste effect, there is a negative allocation effect because the ban on imports stimulates domestic production in the heavily protected rice sector. This results in misallocation of resources.

Is it still worthwhile for China to invest in GM rice if other countries ban GM rice imports from China? The aggregate welfare measure against which the trade ban impact can be evaluated indicates that the export ban does not significantly change the benefits of adopting GM rice in China. Although output growth in the rice sector is somewhat dampened, the overall negative effect on China is small. The largest adoption gains are realized within China itself. As far as rice is concerned, the negative attitude towards GM food products in some high-income countries is of little concern to China.

\subsection{Labelling}

In this scenario, China requires the labelling of soybean imports from NAFTA and South America. While soybean imports will be subject to a very low tariff (3\%) as an outgrowth of the WTO accession agreement, there is a discussion about the implementation of a labelling system for soybean imports that distinguishes GM varieties. In January 2002 the Chinese Ministry of Agriculture announced three new regulations on the biosafety management, trade and labelling of GM farm products. These regulations came into effect on 20 March 2002 and require importers of genetically modified agricultural products to 
apply to China's Ministry of Agriculture for official safety verification approval. Since China is the largest market for US soybean exports (China's purchases amounted to over USD 1 billion in 2001) it is not surprising that US producers have accused Beijing of using the new rules to hinder imports in order to protect Chinese soybean growers. After two months of intensive negotiation between China and the US, recently an interim deal was reached under which China will temporarily waive its regulations and will recognize US assurances that its soybeans are safe for human consumption. The other main sources of soybean imports into China are countries that also have embraced the benefits of herbicidetolerant (Round-Up Ready) GM soybeans, that is, Argentina and Brazil.

However, labelling is not only introduced for imports. Domestic produce has to be labelled as well. ${ }^{1}$ The simulation experiment in this section provides an assessment of the economic effects if indeed China is to label its own GM food crops, given that it exercises labelling requirements for imported soybeans. In our case, this means that China has to implement labelling for GM rice only, as there is no GM soybean production in China.

In this scenario we do not model separate production-consumption chains for GM and non-GM varieties. One consequence of this simplification is that we are unable to quantify any (positive or negative) price premium that GM varieties might achieve on the Chinese market. It is not possible to include in our analysis the valuation of consumers for GM varieties. We are also not in a position to include estimates of costs to be incurred for separating the two chains, such as monitoring and inspection costs. Our analysis is based on a rather straightforward assumption about labelling costs for both imported and domestic GM crops.

The labelling of GM rice in China is modelled as an increase in the cost of services required for rice production. We assume that total production costs will increase by $3 \%$ through labelling. The labelling of GM soybeans is modelled as an increase in the 'transport/handling' margin between FOB and CIF for soybean exports from NAFTA and South America (SAM) to China. We assume that these handling costs will increase so much that the total import costs (c.i.f. price from NAFTA or SAM to China) will increase by $5 \%$. It should be noted that we assume here that only NAFTA and SAM labels their soybeans that are exported to China. Labelling by other countries, most notably the EU, is not included.

\footnotetext{
${ }^{1}$ Hence, the Chinese labelling requirements are in accordance with the GATT principle of national treatment, as enshrined in Article 3 of the GATT. National treatment applies only once the product (or service or item of intellectual property right) has entered the national market.
} 


\begin{tabular}{lcc}
\hline & $\begin{array}{c}\text { Bt cotton \& GM rice } \\
\text { adoption with } \\
\text { GM rice trade ban }\end{array}$ & $\begin{array}{c}\text { Labelling soybean } \\
\text { imports and domestic } \\
\text { rice }\end{array}$ \\
\hline Rice & & -9.3 \\
CHINA & & 0.6 \\
Supply price & -12.1 & -7.2 \\
Output volume & 1.4 & -18.5 \\
Export volume & 5.3 & -14 \\
Import volume & -23.7 & \\
Trade balance (USD million) & 19 & 7.1 \\
Soybean & & -14.1 \\
NAFTA & & 6.2 \\
Import price China (c.i.f.) & 0.0 & -10.7 \\
Export volume to China & 0.4 & 0.3 \\
SOUTH AMERICA & & 2.7 \\
Import price China (c.i.f.) & 0.0 & -1.5 \\
Export volume to China & 0.4 & -6.1 \\
CHINA & & 58 \\
Supply price & -0.1 & 3,953 \\
Output volume & 0.7 & \\
Export volume & 0.1 & \\
Import volume & 0.4 & \\
Trade balance (USD million) & -13 & \\
Welfare (USD million) & 5,229 & \\
& & \\
& &
\end{tabular}

Source: model simulations.

Table 11 shows the costs of labelling both imported soybeans and domestic rice. The domestic supply price of rice increases relative to the previous experiment, but still a price decline of almost $10 \%$ relative to the baseline is projected. The higher domestic supply price leads to fewer exports, less output and more rice imports. The labelling of imported soybeans increases the equilibrium import price of soybeans from NAFTA and South America by $7.1 \%$ and $6.2 \%$, respectively, resulting in a considerable drop in soybean exports from these regions. Total Chinese soybean imports decline by $6 \%$ because soybeans from NAFTA and SAM account for $77 \%$ of all Chinese soybean imports.

Labelling is costly. Measured in terms of equivalent variation - and bearing in mind that we do not include any positive utility effects that might exist when consumers have access to improved product information - the welfare loss to China is about USD 1.3 billion. However, even when a trade ban and labelling occur together, we still observe a very positive welfare impact of adopting GM crops (almost USD 4 billion).

This experiment highlights an important trade-off that China is facing. The labelling of imported soybeans raises the domestic price of soybeans, and benefits Chinese soybean farmers, who will see a shift towards cheaper domestic demand and are able to increase output at higher prices. However, the domestic labelling of GM foods also raises the price of domestic rice, and this affects rice consumers. Hence, labelling improves the 
competitive position of domestic (non-GM) soybean farmers, as such soybeans become cheaper relative to imports, but it hurts rice consumers.

Our experiments considered only unilateral GM labelling by China. As a consequence, some soybean trade is diverted to EU markets, which does not adopt labelling in our scenario. If this alternative outlet for US and South American soybeans does not exist, the price effects on imported soybeans will be smaller. 


\section{Conclusions}

China is developing the largest public plant biotechnology capacity outside of North America. The international debate about GM technologies influences Chinese policymaking and the country's agricultural industry. The adoption of $\mathrm{Bt}$ cotton has been proceeding at a rapid pace in recent years. The largest part of the potential productivity gains from Bt cotton will be realized already by 2005 , thereafter the productivity growth will slow down. In contrast, GM rice is not yet available to farmers on a commercial basis, and our estimates indicate that large productivity gains are to be realized between 2005 and 2010.

This report uses productivity estimates for GMOs that are based on empirical micro-level data for the cotton sector and tentative experimental data for the rice sector in China. Biotechnology leads to crop-specific, factor-biased technical change, and the results show that the distinction between yield factor and production factor effects is important. Factor markets for labour and land will witness different effects, depending on the type of biotechnology being adopted. The scarce land resources can be utilized more effectively by applying land-saving technologies. Even though labour is relatively abundant in China, the adoption of somewhat labour-saving GM crops will not necessarily lead to falling wages. This is especially the case in $\mathrm{Bt}$ cotton. Here, the expansion of the cotton sector itself, together with rising labour demand from the unskilled-labour-intensive textiles sector, more than compensates for the savings in labour inputs obtained by adopting the GM crop. The use of empirical estimates that give a better indication of the magnitudes of the productivity impact of GMOs is certainly very important.

The economic gains from GMO adoption are substantial. In the most ptimistic scenario - where China commercializes both Bt cotton and GM rice - the welfare gains amount to an additional annual income of about USD 5 billion in 2010. This amounts to about USD 3.5 per person. This is not a small amount in a country where, according to the World Bank, $18 \%$ of the population had to survive on less than USD 1 per day in $1998 .{ }^{1}$ Given the importance of rice for agricultural production, employment and food budget shares, the gains from GM rice adoption are orders of magnitude larger than the Bt cotton gains. The estimated macro economic welfare gains far outweigh the public biotechnology research expenditures.

Although the productivity gains for China are significant and translate to rising exports and/or reducing imports, the patterns of global trade in both the textiles and garments sector and the rice sector are not affected very much. The impact is negligible both on major rice importers (e.g. Africa and some rice-deficit developing countries in Asia) and on major rice exporters (i.e. Thailand, Vietnam and Burma). The Chinese biotechnology research strategy has concentrated primarily on crops that are of great importance to rural livelihoods, rather than on those that are important in terms of export

\footnotetext{
${ }^{1}$ World Development Indicators. International poverty line of USD 1 (PPP adjusted) in 1998. 32
} 
earnings. Rice exports from China represent only a small share of the international rice trade. The immediate impact is small on other major cotton exporters, most notably India and Pakistan. The cost savings and yield increases from Bt cotton translate into lower production costs for the Chinese textiles and garments industry, but these cost reductions are not so great that other garment producers (e.g. India and Bangladesh) are affected very much. The phasing out of the Multifibre Agreement by 2005 is of greater importance for the global trade in textiles and garments than Bt cotton commercialization in China.

Our results indicate that trade restrictions will not significantly lower the gains from biotechnology research in China. A trade ban on GM rice (food crop) would have only a minor effect, since the portion of rice exported is very small. The effects of the unilateral labelling of soybean imports would be larger and have clear distributional impacts. Our experiments highlight an important trade-off that China is facing: if China labels GM products, this will raise the domestic price of soybeans and thus benefit Chinese soybean farmers. However, domestic labelling would also raise the price of domestic GM rice, and this would affect rice consumers. Our findings suggested that China should continue to promote its GM biotechnology, including commercializing its GM food crops. Policy makers should put less weight on the international dimension when making their decisions about biotechnology development.

This report provides an economic analysis of some of the issues surrounding the rapid adoption of biotechnology in China. Despite being based on the comprehensive general equilibrium model and an associated global database, a number of limitations should be borne in mind when interpreting the results. First of all, in this report no utility is attached to improved product information. That is, especially in our labelling experiments, we are unable to quantify the possible positive effects that labelling may have on consumers' welfare. Our study provides an estimate of the economy-wide cost of labelling. We are also unable to provide a separate modelling of the GM and non-GM supply chains, and consequently cannot provide estimates of the price premiums that occur due to preference shifts. 


\section{References}

Anderson, K., Yao, S., 'China, GMOs and world trade in agricultural and textile products'. Paper presented at the International Workshop on Plant Biotechnology Policy in China. Center for Chinese Agricultural Policy, Chinese Academy of Sciences, Beijing, 18-20 July 2001.

Biotechnology Research Institute (BRI), Chinese Academy of Agricultural Sciences, 2000. 'Research achievements of Biotechnology Research Institute'. In: Review of China Agricultural Science and Technology 2(2000) 2, pp. 37-38.

Chen, Z., 'Review of R\&D on plant genetic engineering in China'. Paper presented at the China-ASEAN Workshop on Transgenic Plants, Beijing, China, 30 July-5 August 2000.

European Commission, Economic Impacts of Genetically Modified Crops on the AgriFood Sector: A Synthesis. 2001.

Guo, S., Cui, H., 'New research progress on insect-resistant transgenic cotton'. Chinese Agricultural Science 6 (1998) 1, pp. 7-13.

Guo, S., Cui, H., 'Synthesization of GFM Cry1A insecticidal gene and construction of plant expression vectors in insect-resistant transgenic cotton'. In: Review of China Agricultural Science and Technology, 2 (2000) 2, pp. 21-26.

Hertel, T.W. (ed.)., Global Trade Analysis: Modelling and Applications. Cambridge University Press, 1997.

Hertel, T. W., Anderson, K., Hoekman, B., Francois, J. F., and Martin, W., 'Agriculture and nonagricultural liberalization in the millennium round'. Paper presented at the Agriculture and New Trade Agenda, Geneva, Switzerland, 1-2 October 1999.

Hicks, J.R., The Theory of Wages. London: Macmillan and Co. Ltd, 1932.

Huang, J., Wang, Q., Zhang, Y., and Falck-Zepeta, J.B., 'Agricultural biotechnology development and research capacity in China'. Discussion paper. International Service for National Agricultural Service, Hague, the Netherlands, 2001.

Huang, J., Rozelle, S., Pray, C., and Wang, Q., 'Plant biotechnology in China'. In: Science 295 (2002), pp. 674-677. 
Huang, J., Hu, R., Pray, C., Rozelle, S., and Qiao, F., 'Smallholders, transgenic varieties, and production efficiency: the case of cotton farmers in China'. In: Australian Journal of Agricultural and Resource Economics, 46 (2002) 3, pp. 1-21.

Huang, J., Rozelle, S., China's Grain Economy Toward the 21st Century. China's Agricultural Press, Beijing, 1998.

James, C., Global Status of Commercialized Transgenic Crops. ISAAA, 2002.

Key Laboratory of Crop Molecular and Cell Biology (KLCMCB), Ministry of Agriculture, The Research and Prospects of Crop Genetic Engineering. Chinese Agricultural Science and Technology Press, Beijing, 1996.

Li, N., 'Review of safety administration implementation regulation on agricultural biological genetic engineering in China'. Paper presented at the China-ASEAN Workshop on Transgenic Plants, Beijing, China, 30 July-5 August 2000,

NCBED (National Center of Biological Engineering Development), 'The research progress in biotechnology'. In: Biological Engineering Progress 20 (2000) Special Issue.

NSBC (National Statistical Bureau of China), Statistical Yearbook of China. China Statistical Press, Beijing, 2000.

Pray, C., Ma, D., Huang, J. and Qiao, F., 'Impact of Bt cotton in China'. In: World Development 29 (2001), pp. 813-825.

Pray, C., Huang, J., and Rozelle, S., 2002. 'Five years of Bt cotton in China: the benefits continued', In: The Plant Journal, 31 (2002) 4, pp. 423-430.

SSTC (State Science and Technology Commission), Development Policy of Biotechnology. The Press of Science and Technology, Beijing, 1990.

Van Meijl, H., van Tongeren, F., Huang, J. and Li. N., A baseline projection for China's agriculture and global trade: 2001-2020. LEI/CCAP working paper, 2002.

Van Meijl, H., van Tongeren, F., 'International diffusion of gains from biotechnology and the European Union's Common Agricultural Policy'. Paper prepared for the 5th Annual Conference on Global Economic Analysis, Taipei, Taiwan, 5-7 June, 2002.

Walmsley, T. L., Dimaranan, B., and McDougall, R. A., A base case scenario for the dynamic GTAP model. Center for Global Trade Analysis, Purdue University, West Lafayette (IN), 2000.

World Bank, World Development Indicators. The World Bank, Washington D.C., 2000. 
Zhang, C., 'The development of transgenic hybrid rice resistant to stem borer'. In: Biotechnology Information 15 (1999) 6, pp. 58.

Zhu, Z., 'Development of highly insect-resistance transgenic rice'. Paper presented at the International Symposium on Development of Plant Gene Engineering and its Biosafety. Beijing, China, 26-27 November 2000. 


\section{Appendix Table A: Regional and sector aggregations}

Description

\begin{tabular}{ll}
\hline $\begin{array}{l}\text { China } \\
\text { Hong Kong } \\
\text { Taiwan } \\
\text { JapKor }\end{array}$ & $\begin{array}{l}\text { Mainland, China } \\
\text { Hong Kong, China } \\
\text { Taiwan, China } \\
\text { Japan and Korea } \\
\text { South East Asia }\end{array}$ \\
OthAsia & Other Asia \\
AusNzl & Australia and New Zealand \\
NAFTA & North American free trade area \\
SAM & South and Central America
\end{tabular}

EU15 European Union

CEEC Central and East European

ROW Rest of World

\section{Regional aggregation}

\author{
Mainland, China \\ Hong Kong, China \\ Taiwan, China \\ Japan, Korea \\ Indonesia, Vietnam, Malaysia, Philippines, Thailand, \\ Singapore \\ Bangladesh, India, Sri Lanka, rest of south Asia \\ Australia, New Zealand \\ Canada, United States, Mexico \\ Central America, Caribbean, Colombia, Peru, Venezuela, \\ rest of Andean Pact, Argentina, Brazil, Chile, Uruguay, rest \\ of South America \\ Austria, Belgium, Denmark, Finland, France, Germany, \\ United Kingdom, Greece, Ireland, Italy, Luxembourg, \\ Netherlands, Portugal, Spain, Sweden \\ Hungary, Pollen, rest of CEEC
}

Switzerland, rest of Efta, Turkey, rest of Middle East, Morocco, rest of North Africa, Malawi, Mozambique, Tanzania, Zambia, Zimbabwe, Other Southern Africa, Uganda, rest of Sub-Saharan Africa, Former Soviet Union, Botswana, rest of Sacu, rest of world Sector aggregation

\begin{tabular}{ll}
\hline Rice & Rice, paddy and processed \\
Wheat & Wheat \\
Cgrains & Coarse grains \\
Oilseeds & Oilseeds and vegetable oils \\
Sugar & Sugar raw and processed \\
Pfb & Plant based fibers \\
Othcrop & Horticulture and other crops \\
Ctl & Cattle and red meat \\
Oap & Pig \& poultry- white meat, wool \\
& \\
Milk & Raw milk and dairy products \\
Fish & Fish \\
Ofood & Food products nec \\
Extract & Natural resources and extract \\
Texlea & Textiles and leather \\
Labintman & Labour intensive Manfact \\
& \\
Capintman & Capital intensive manufact
\end{tabular}

Paddy rice, processed rice

Wheat

Cereals grains nec

Oilseeds, vegetable oils and fats

Sugar cane, sugar beet, Sugar

Plant based fibers

Vegetables fruit nuts, crops-nec

Cattle, sheep, goats, horses and their meats

Animal products nec, wool, silk-worm cocoons, meat products nec

Raw milk, dairy products

Fish

Food products nec, beverages \& tobacco products

Forestry, coal, oil, gas, minerals nec

Textiles, wearing apparel, leather products

Wood and paper products, publishing, metal products, motor vehicles and parts, transport equipment nec Petroleum, coal products, chemical rubber plastic prods, mineral products nec, ferrous metals, metals nec, electronic equipment, machinery and equipment nec, manufactures nec

Svces $\quad$ Services and activities NES
Electricity, gas manufacture, distribution, water, construction, trade, transport nec, sea transport, air transport, communication, financial services nec, insurance, business services nec, recreation and other, pubadmin/defence/health/educat, dwellings 
